\title{
Chemical composition and antimicrobial activity of two extract of propolis against isolates of Staphylococcus spp. and multiresistant bacterials ${ }^{1}$
}

\author{
Jarbas F. Amarante², Márcia F. Ribeiro³, Mateus M. Costa², Fredson G. Menezes², \\ Tania M.S. Silva ${ }^{4}$, Talita A.B. Amarante ${ }^{5}$, Adriana Gradela ${ }^{2 *}$ (D) \\ and Liliane M.D. Moura ${ }^{2}$
}

\begin{abstract}
Amarante J.F., Ribeiro M.F., Costa M.M., Menezes F.G., Silva T.M.S., Amarante T.A.B., Gradela A. \& Moura L.M.D. 2019. Chemical composition and antimicrobial activity of two extract of propolis against isolates of Staphylococcus spp. and multiresistant bacterials. Pesquisa Veterinária Brasileira 39(9):734-743. Laboratório de Anatomia dos Animais Domésticos e Silvestres, Colegiado de Medicina Veterinária, Universidade Federal do Vale do São Francisco, Rodovia 407 Km 12, Lote 543, Projeto Nilo Coelho C1, Petrolina, PE 56300-000, Brazil.E-mail: agradela@hotmail.com

There is a growing need to discover and develop alternative therapies for the treatment of mastitis caused by Staphylococcus spp. and multidrug-resistant bacterial infections. This study examined the chemical composition and antimicrobial potential of two propolis extracts (EPA and EPB) against seventy-seven isolates of Staphylococcus spp. obtained from subclinical bovine mastitis; three clinical strains of MRSA and two from clinical strains of $S$. aureus ATCC, identified as S. aureus ATCC 6538 and S. aureus ATCC 25923. The total phenolic content was determined by the Folin-Ciocalteau method, the total flavonoid content by the Dowd method and the phenolic profile was quantified by HPLC-DAD. The MBC values of the extracts were evaluated by broth microdilution method. The amount of total phenolic and flavonoid compounds was higher in EPA than EPB. Both extracts revealed the presence of caffeic, coumaric, cinnamic, ferulic and 3,4-dihydroxybenzoic acids, with higher concentrations of coumaric and cinnamic acids. Staphylococcus spp. isolates were susceptible to EPA (90.9\%), EPB (83.1\%) and oxacillin (80.5\%). The oxacillin susceptible isolates were also susceptible to EPA (70.1\%) and EPB (80.6\%), whereas those oxacillin-resistant strains were also susceptible to EPA (40.0\%) and to EPB (26.7\%). MBC ranged from 34.3 to $68.7 \mu \mathrm{m} / \mathrm{mL}$ for EPA and from 68.7 to $137.5 \mu \mathrm{g} / \mathrm{mL}$ for EPB. Both extracts inhibited significantly (100\%) the clinical strains of MRSA, S. aureus ATCC 6538 and S. aureus ATCC 25923 at the concentration of $68.7 \mu \mathrm{g} / \mathrm{mL}$. It is concluded that both extracts of propolis, whose main constituents are coumaric and cinnamic acids, have high antimicrobial activity against the microorganisms studied, and EPA also against oxacillin-resistant strains. These findings reinforce its potential use for the treatment of bovine mastitis.
\end{abstract}

INDEX TERMS: Chemical composition, antimicrobial activity, extract of propolis, Staphylococcus spp., multiresistant bacterials, phenolic compounds, microdilution, oxacillin-resistant Staphylococcus aureus, propolis, bacterioses.

\footnotetext{
${ }^{1}$ Received on November 25, 2018.

Accepted for publication on May 9, 2019.

${ }^{2}$ Universidade Federal do Vale do São Francisco (Univasf), Rodovia 407 Km 12, Lote 543, Projeto Nilo Coelho C1, Petrolina, PE 56300-000, Brazil. *Corresponding author: agradela@hotmail.com

${ }^{3}$ Centro de Pesquisa Agropecuária do Trópico Semi-Árido (CPATSA), Empresa Brasileira de Pesquisa Agropecuária (Embrapa), Rodovia BR-428,
}

Km 152, Zona Rural, Petrolina, PE 56302-970.

${ }^{4}$ Departamento de Ciências Moleculares, Universidade Federal Rural de Pernambuco (UFRPE), Rua Manuel de Medeiros s/n, Dois Irmãos, Recife, PE 52171-900, Brazil.

${ }^{5}$ Departamento de Ciências Humanas (DCH), Universidade do Estado da Bahia (UNEB), R. Silveira Martins 2555, Cabula, Salvador, BA 41150-000, Brazil. 
RESUMO.- [Composição química e atividade antimicrobiana de dois extratos de própolis contra isolados de Staphylococcus spp. e bactérias multirresistentes.] É cada vez mais oportuna a necessidade de descobrir e desenvolver terapias alternativas para tratamento da mastite causada por Staphylococcus spp. e de infecções bacterianas multirresistentes. Este estudo examinou a composição química e o potencial antimicrobiano de dois extratos etanólicos de própolis (EPA e EPB) contra setenta e sete isolados de Staphylococcus spp. obtidos a partir de mastite bovina subclínica; três estirpes clínicas de MRSA e duas de linhagens clínicas de $S$. aureus ATCC, identificadas como, S. aureus ATCC 6538 e S. aureus ATCC 25923, ambas metacilina resistentes. 0 teor total de fenólicos foi determinado pelo método de Folin-Ciocalteau, o teor de flavonoides totais pelo método Dowd e o perfil fenólico foi quantificado por HPLC-DAD. CBM dos extratos foi avaliada pelo método de microdiluição em caldo. A quantidade total de compostos fenólicos e flavonoides foi maior no EPA do que no EPB. Ambos os extratos revelaram a presença dos ácidos cafeico, cumárico, cinâmico, ferúlico e 3,4-di-hidroxibenzóico, com maiores concentrações de ácidos cumárico e cinâmico. Os isolados de Staphylococcus spp. foram sensíveis a EPA (90,9\%), EPB $(83,1 \%)$ e oxacilina $(80,5 \%)$. Os isolados suscetíveis à oxacilina também foram suscetíveis ao EPA $(70,1 \%)$ e ao EPB $(80,6 \%)$, enquanto os do resistente à oxacilina foram suscetíveis ao EPA $(40,0 \%)$ e ao EPB (26,7\%). MBC variou de 34,3 a $68,7 \mu \mathrm{m} / \mathrm{mL}$ para EPA e de 68,7 a $137,5 \mu \mathrm{g} / \mathrm{mL}$ para EPB. Ambos os extratos inibiram significativamente (100\%) as linhagens clínicas de MRSA, S. aureus ATCC 6538 e S. aureus ATCC 25923 na concentração de $68,7 \mu \mathrm{g} / \mathrm{mL}$. Conclui-se que os extratos etanólicos da própolis, cujos principais constituintes são os ácidos cumário e cinâmico, possuem atividade antimicrobiana contra os micro-organismos estudados, e o EPA também contra as cepas resistentes à oxacilina. Estes achados reforçam seu potencial uso para o tratamento da mastite bovina.

TERMOS DE INDEXAÇÃO: Composição química, atividade antimicrobiana, extrato de própolis, Staphylococcus spp., bactérias multirresistentes, compostos fenólicos, microdiluição, Staphylococcus aureus oxacilina-resistente, própolis, bacterioses.

\section{INTRODUCTION}

In Brazil, milk production is a very important segment, totaling 25.4 billion liters annually. Mastitis is the main disease that affects dairy production, with a prevalence of $48.64 \%$ in the subclinical form (Acosta et al. 2016), causing changes in the physical-chemical composition and cellularity of the milk, resulting in high economic damages with the reduction in milk production and significant effects on public health (Langoni 2000, Ribeiro 2008).

Approximately 140 different etiological agents may cause bovine mastitis, mainly in the subclinical form, of which the most prevalent contagious microorganisms have been Staphylococcus aureus, Streptococcus spp., Streptococcus agalactiae, Staphylococcus spp. and Corynebacterium bovis, in pure culture or in association (Costa 2001, Santos \& Fonseca 2007, Ribeiro et al. 2009, Martins et al. 2010, Peixoto et al. 2012, Saeki et al.2012). S. aureus is recognized worldwide as a cause of several purulent diseases in humans and animals (Bean \& Griffin 1990) and also an important cause of food poisoning in humans (Omoe et al. 2002). Additionally this, it shows persistence in the mammary tissue, due to the characteristics of its virulence (Dos Santos et al. 2003) and the appearance of resistant strains by the inadequate use of antibiotics in the treatment of diseases (Barberio et al. 2002, Hogeveen et al. 2011). Methicillin-resistant Staphylococcus aureus (MRSA) strains are one of the most prevalent in cases of mastitis and have as main characteristic to be multiresistant to the antimicrobials of the beta-lactam group (Freitas et al. 2005).

One of the main tools for the control and treatment of mastitis is antimicrobial therapy (Erskine et al. 2003), but its efficiency is compromised in cases of antimicrobial resistance (Russi et al. 2008, Shi et al. 2010, Spohr et al. 2011). In addition, the use of antimicrobials causes severe economic losses due to the discarding of animals (Silva et al. 2004) and milk (Nero et al. 2007), reduction of milk production and drug costs (Vianni \& Lázaro 2003).

The use of phytotherapics has been shown to be a very useful tool for the prevention and treatment of mastitis, as well as avoiding the elimination of residues in milk (Schiavon et al. 2011). In this sense, propolis, a resinous product produced by honey bees, is being used in the treatment of human and animal diseases (Coelho et al. 2010) and has been shown to be a viable and quite promising alternative in the treatment of infections caused by S. aureus (Pinto et al. 2001, Endler et al. 2003, Auricchio et al. 2006, Zeighampour et al. 2014, Shahbaz et al. 2015, Chen et al. 2018) due to its proven antibacterial activity (Barbosa et al. 2009, Araujo \& Marcucci 2011). However the results using propolis are still conflicting (Pinto et al. 2001, Loguercio et al. 2006, Peixoto et al. 2012), due to its distinct and complex chemical constitution, necessitating the development of further research (Lustosa et al. 2008, Rufatto et al. 2017). In addition, there are few conclusive results regarding their action against MRSA, that play an important role in nosocomial infections (Taubes 2008) and a serious problem on a global scale (Astani et al. 2013). Brazil is the third largest producer of propolis, contributing $10-15 \%$ of the worldwide production (Pereira et al. 2002), for this reason studies about the antibacterial activity of Brazilian propolis would contribute to further increase this participation.

The present study investigated the chemical composition and the antimicrobial activity of two extracts of propolis against isolates of Staphylococcus spp. obtained from subclinical bovine mastitis and also clinical strains of MRSA and Sthaplococcus aureus ATCC 6538 and ATCC 25923.

\section{MATERIALS AND METHODS}

Propolis extracts. The bacterial isolates were tested against two commercial extracts of propolis identified as extract of propolis A (EPA) and extract of propolis B (EPB). The EPA was an $11 \%$ green propolis extract (Apis Flora ${ }^{\circledR}$ ) originating from the Vassourinha do campo (Baccharis dracunculifolia) and obtained from hives of Jundiai, state of São Paulo. It consists of the following ingredients: green propolis, neutral alcohol (ethanol) $95.1 \%$ food grade and purified water. The EPB was also in 11\% neutral propolis and alcohol solution (Santa Bárbara ${ }^{\circledR}$ ). It was obtained from hives in the State of Bahia, containing in its composition 55\% plant resins; 30\% beeswax; 8 to $10 \%$ of essential oils; and $5 \%$ pollen. Both extracts had its chemical composition analysed at the Laboratory of Natural Products of the "Universidade Federal Rural de Pernambuco" (UFRPE), in Recife, Pernambuco. 
Determination of total phenolic content. Quantification of phenolic compounds in the EPA and EPB was performed by the Folin-Ciocalteau method using gallic acid as the standard (Singleton \& Rossi Junior 1965). The standard curve of gallic acid had five points of concentration $(4,8,16,24,36 \mu \mathrm{g} / \mathrm{mL})$, with a wavelength of $760 \mathrm{~nm}$, with $\mathrm{Y}=0.0064 \mathrm{x}+0.4174$, where $\mathrm{y}$ is the absorbance and $\mathrm{x}$ is the concentration; $\mathrm{R}^{2}=0.9577$. Quantification of phenolic compounds in extracts of propolis was performed in triplicate, with the quantity of phenols expressed in mg of gallic acid equivalent per gram of propolis extract, given the dry extract content (Roesler et al. 2007).

Determination of total flavonoids. The total flavonoid content in the EPA and EPB was determined by the adapted Dowd method (Meda et al. 2005), with absorbance readings at $300 \mathrm{~nm}$, constructing a standard curve of quercetin in five concentrations $(1,5,10,20,40 \mu \mathrm{g} / \mathrm{ml})$, with $Y=0.0198 x+0.3552$, where " $y$ " is the absorbance and " $\mathrm{x}$ " is the concentration; $\mathrm{R}^{2}=0.9807$. The total flavonoid content was expressed as mg of quercetin equivalent per gram of propolis extract, given their dry extract content, as described by Lee et al. (2003).

Determination of dry residue content. An aliquot of $5 \mathrm{~mL}$ of EPA and EPB, free of wax, was transferred to a porcelain capsule in dry form (heated in a laboratory oven at $105^{\circ} \mathrm{C}$, for $2 \mathrm{~h}$, cooled in a desiccator and weighed), and the whole was taken to the oven preheated to $105^{\circ} \mathrm{C}$, where it remained for $2 \mathrm{~h}$. After cooling in desiccator, the set was weighed. The process of heating, cooling and weighing the assembly was repeated at intervals of $1 \mathrm{~h}$ until a constant mass was reached (when the difference between two consecutive weighing did not exceed $5 \mathrm{mg}$ ). This analysis was realized in triplicate and the dry residue content (soluble solids in methanol) calculated by the ratio of the mass of the residue deposited in the crucible to the initial mass of the extracts of propolis crude corresponding to the aliquot of $5 \mathrm{~mL}$ in percent (Instituto Adolfo Lutz 1976, Brasil 2001, European Pharmacopoeia 2002).

HPLC-DAD analysis. The High Performance Liquid Chromatography (HPLC) system consisted of two SCL-10Avp solvent pumps, equipped with a SPDM20 diode array detector (HPLC-DAD; Shimadzu, Corp., Kyoto, Japan). Samples were injected into a Rheodyne 7125i type injector with a $20 \mathrm{~mL}$ capacity loop. Chromatographic separation was done with a C-18 column $(25 \mathrm{~cm} \times 4.6 \mathrm{~mm} \times 5 \mathrm{~mm}$, Shimpack CLC-ODS), pre-column C-18 SULPELCO $4.0 \mathrm{~mm}$. Water: formic acid (99: 1, solvent A) and methanol (solvent B) were used as the mobile phase and water was used for the acid derivatives: formic acid (95:5, solvent A) and methanol (solvent B). The chromatographic condition was: $0-15 \mathrm{~min} 20 \% \mathrm{~B}, 15-20 \mathrm{~min} 30 \% \mathrm{~B}, 20-30 \mathrm{~min} 40 \%$ $\mathrm{B}, 30-40 \mathrm{~min} 40 \% \mathrm{~B}$, with flow rate of $1.0 \mathrm{~mL} / \mathrm{min}$. For monitoring, the wavelength of $290 \mathrm{~nm}$ and temperature of $40^{\circ} \mathrm{C}$ (Dalmora et al. 1997) were used. The identification of phenolics was based on retention times, UV-spectra and chromatographic comparison (co-injection) with authentic markers.

The caffeic, p-coumaric, ferulic, cinnamic, and 3,4-dihydroxybenzoic acids identified in propolis were quantified using the external standard method based on EPAk area. Analyses were made by drawing a calibration curve. To make the calibration curve of each phenolic compound, appropriate volumes from each stock solution were diluted with methanol to obtain working solutions in the concentration range of $0.5-40 \mathrm{mg} / \mathrm{mL}$ that were correlated with the measured area. The area of these EPAk was drawn and the corresponding concentration of phenolics was calculated based on the calibration curve. For each sample, the quantitative analyses were performed in triplicate at $290 \mathrm{~nm}$.

Reagents and standards. Ferulic, 3-hydroxy-4-methoxycinnamic, caffeic, p-coumaric, cinnamic, sinapic, 4- methoxycinnamic, 3,4- dihydroxybenzoic, 4-hydroxybenzoic and syringic acids were obtained from Sigma-Aldrich (Hamburg, Germany), gallic and vanillic acids were obtained from Fluka Chemie AG (Buchs, Switzerland). All reagents used were analytical grade, as well as formic acid (Vetec, Brazil) and methanol (TEDIA).

Tested samples. The antimicrobial activity of EPA and EPB was analysed at the Animal Microbiology and Immunology Laboratory of the "Universidade Federal do Vale do São Francisco" (Univasf), in Petrolina, Pernambuco State, using seventy-seven isolates of Staphylococcus spp. obtained from cases of subclinical bovine mastitis in dairy farms in the Northeast region of Brazil. They were also tested three multiresistant isolates, one being Methicillin-resistant Staphylococcus aureus (S. aureus) (MRSA) and two from clinical strains of $S$. aureus ATCC, identified as ATCC 6538 and ATCC 25923, both methicillin-resistant.

Microdilution and minimum bactericidal concentration (MBC). The antimicrobial activity of the EPA and EPB was determined as the minimum bactericidal concentration (MBC) against Staphylococcus spp. isolates $(\mathrm{n}=77)$ and clinical strains of MRSA (n=3), S. aureus ATCC $6538(\mathrm{n}=1)$ and S. aureus ATCC 25923 $(\mathrm{n}=1)$. The samples plated on the TSA culture medium (Tryptone Soy Agar), were inoculated in tubes containing $3 \mathrm{~mL}$ of Mueller Hinton (MH) broth medium, in order to perform microdilution according to Clinical And Laboratory Standards Institute (2006). After $24 \mathrm{~h}$, the medium was turbid at 0.5 on the Mac Farland scale $(1 \mathrm{x} 108 \mathrm{CFU} / \mathrm{ml})$ and $0.1 \mathrm{~mL}$ of this suspension was inoculated into tubes containing $9.9 \mathrm{~mL}$ of MH broth (NCCLS 2002). Subsequently, microdilution was performed by placing $200 \mu \mathrm{L}$ of pure, sterile $\mathrm{MH}$ broth in each well of the microplate and then $200 \mu \mathrm{L}$ of each extract in the first well, followed by a 1:2 dilution and discarding the last $200 \mu \mathrm{L}$, with the concentration varying from $0.26 \mu \mathrm{g} / \mathrm{ml}$ to $550 \mu \mathrm{g} / \mathrm{ml}$. Then each well was inoculated with $10 \mu \mathrm{L}$ of the suspension containing the microorganisms. These wells and the positive control wells and negative control were incubated for $24 \mathrm{~h}$ at $37^{\circ} \mathrm{C}$. The contents of each of these wells were inoculated into petri dishes containing $\mathrm{MH}$ agar medium and incubated for $24 \mathrm{~h}$ at $37^{\circ} \mathrm{C}$. The lowest concentration of extract in which there was no growth of the microorganisms in the plaques was considered the MBC (NCCLS 2002). All samples were tested in triplicate.

Oxacillin susceptibility test. The sensitivity test was performed in all samples, in triplicate, by the modified Kirby-Bauer disk diffusion method (Clinical And Laboratory Standards Institute 2006), with microbial turbidity on the 0.5 scale of Mac Farland in $\mathrm{MH}$ broth. Samples were transferred with sterile swab to $\mathrm{MH}$ agar plates, in which the oxacillin-containing discs $(1 \mu \mathrm{g})$ were applied. The plates are incubated in an oven for $24 \mathrm{~h}$ at $37^{\circ} \mathrm{C}$. The breakpoint was determined according to (Clinical And Laboratory Standards Institute 2006).

Statistical analysis. The hypotheses are related to the antibacterial activity potential in vitro of two commercial extracts of propolis against bovine mastitis caused by Staphylococcus spp., in addition to relating them to resistance to oxacillin. The analyzes were performed observing the significance levels of the samples at $1 \%$ and $5 \%$. The results were analyzed using analysis of variance 
(ANOVA) and the probability $\mathrm{p}=0.05$ was considered the critical value for all tests. The Tukey post-hoc test was used to separate statistically significant means. The SAS software Proc Gun model software was used for statistical analysis.

\section{RESULTS}

\section{Analysis of the propolis extracts}

The content of total phenolic and of total flavonoid varied between the samples. The EPA had a total phenolic content of $126.22 \mathrm{mg}(12.62 \%)$ and of total flavonoids of $51.06 \mathrm{mg}$ (5.10\%) and the EPB of $73.12 \mathrm{mg}(7.31 \%)$ and $17.45 \mathrm{mg}(1.74 \%)$, respectively. The dry residue (soluble solids in methanol) content was $11.52 \%$ to the EPA and $10.37 \%$ to the EPB.

The components of each extract were identified by comparison with retention times of known chemical standards commonly found in propolis. The HPLC-DAD chromatograms of EPA and EPB indicated a similar profile of phenolic compounds in both extracts, with the presence, mainly, of cinnamic, ferulic, caffeic, coumaric, and 3,4-dihydroxybenzoic acids in all samples, which were detected according to their retention time and the UV spectral characteristics in comparison to those of standards.

The HLPC-DAD analysis revealed that the EPA presented a concentration of $226.55 \mu \mathrm{g}$ of coumaric acid, $222.55 \mu \mathrm{g}$ of cinnamic acid, $106.87 \mu \mathrm{g}$ of caffeic acid, $7.04 \mu \mathrm{g}$ of ferulic acid and $2.2 \mu \mathrm{g}$ of 3,4-hydroxybenzoic in $5 \mathrm{mg}$ of dry extract of propolis A, and for the EPB the concentrations were, respectively, $130.03 \mu \mathrm{g}, 130.03 \mu \mathrm{g}, 54.86 \mu \mathrm{g}, 3.99 \mu \mathrm{g}$ and $1.05 \mu \mathrm{g}$ in $5 \mathrm{mg}$ of dry extract of propolis B.

\section{Antimicrobial activity of the propolis extracts}

MBC against Staphylococcus spp. isolates ranged from $8.6 \mu \mathrm{g} / \mathrm{mL}$ to $275 \mu \mathrm{g} / \mathrm{mL}$ for the EPA, with a higher $(\mathrm{P}<0.01)$ number of sensitive isolates at the concentration of $68.7 \mu \mathrm{g} / \mathrm{mL}(22 / 70,31.4 \%)$, followed by the concentration of $34.3 \mu \mathrm{g} / \mathrm{mL}(19 / 70,27.1 \%)$. MBC ranged from $2.1 \mu \mathrm{g} / \mathrm{mL}$ to $275 \mu \mathrm{g} / \mathrm{mL}$ for the EPB, with a higher $(\mathrm{P}<0.01)$ number of sensitive isolates at the concentration of $137.5 \mu \mathrm{g} / \mathrm{mL}(19 / 70,56.2 \%)$, followed by concentration of $68.7 \mu \mathrm{g} / \mathrm{mL}(19 / 64,29.7 \%)$. These results indicated that EPA was more effective $(\mathrm{P}<0.01)$ in equal $(22 / 70,31.4 \%)$ or lower $(33 / 70,47.1 \%)$ concentration than $68.7 \mu \mathrm{g} / \mathrm{mL}$, while the EPB was more effective $(\mathrm{P}<0.01)$ in a higher concentration $(38 / 64,59.4 \%)$, presenting similar results at equal concentration $(19 / 64,29.7 \%)$ and lower result at concentrations below $68.7 \mu \mathrm{g} / \mathrm{mL}(7 / 64,10.9 \%)$ (Table 1). MBC against clinical strains of MRSA, ATCC 6538 and ATCC 25923 was also $68.7 \mu \mathrm{g} / \mathrm{ml}$ for both EEP-A and EEP-B.

The analysis of the antimicrobial activity of the extract of propolis showed that $90.9 \%(70 / 77)$ of the 77 isolates of Staphylococcus spp. were susceptible to EPA, 83.1\% (64/77) to EPB, $80.5 \%(62 / 77)$ susceptible to oxacillin and $19.5 \%$
(15/77) resistant to oxacillin. Among Staphylococcus spp. isolates susceptible to oxacillin $70.1 \%$ (44/62) were also susceptible to EPA and 80.6\% (50/62) to EPB, whereas among those resistant to oxacillin $40.0 \%(6 / 15)$ was susceptible to EPA and 26.7\% (4/15) to EPB (Fig.1).

Clinical strains of MRSA and S. aureus ATCC 6538 and S. aureus ATCC 25923 exhibited 100\% susceptibility to both extracts.

\section{DISCUSSION}

This study brings important contributions to the scientific community due to the number of clinical strains of Staphylococcus spp. evaluated, as well as by the potential use of the propolis in the treatment of clinical cases of bovine mastitis and other infections caused by MRSA.

More than 300 constituents have been identified in different propolis samples (Marcucci 1995, Bankova et al. 2000, De Castro 2001, Park et al. 2002, Pietta et al. 2002, Alencar et al. 2007), which proportions depend upon of the place and time of collection (Park et al. 2002). Although the chemical composition and biological properties of propolis are variable, it generally has in its composition resin and vegetable balsam (50\%), wax (30\%), essential and aromatic oils $(10 \%)$, pollen, as well as several other substances (5\%) (Burdock 1998, Park et al. 2002, Pietta et al. 2002). The most important active compounds are flavonoids, terpenoids and phenylpropanoids (García-Lafuente et al. 2009), aromatic acids and phenolic compounds (Garza-González et al. 2010). The total phenolics and flavonoids contents may vary due to different factors, such as flora ecology (Park et al. 2002);

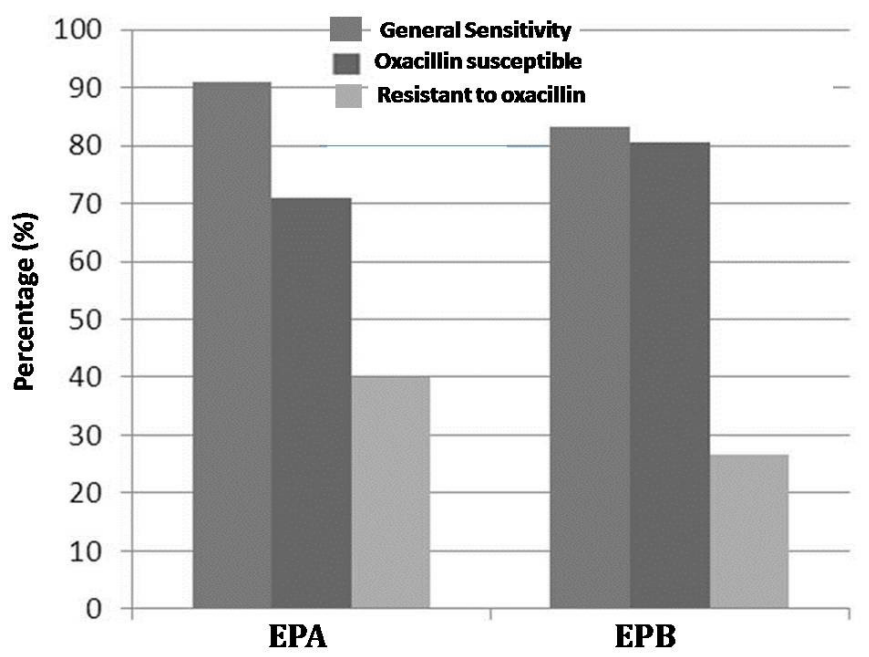

Fig.1. Antimicrobial activity of extract of propolis A (EPA) and B (EPB) on isolates of Staphylococcus spp. susceptible to several antibiotics and susceptible or resistant to oxacillin.

Table 1. Minimum bactericidal concentration (MBC) of the extracts of propolis against isolates of Staphylococcus spp.

\begin{tabular}{|c|c|c|c|c|c|c|c|c|c|c|c|c|c|}
\hline & \multirow{2}{*}{$\begin{array}{l}\text { Total no./ } \\
\text { sensitive }\end{array}$} & \multicolumn{12}{|c|}{ Minimum bactericidal concentration $(\mu \mathrm{g} / \mathrm{mL})$} \\
\hline & & 550 & 275 & 137.5 & 68.7 & 34.3 & 17.1 & 8.6 & 4.3 & 2.1 & 1.1 & 0.53 & 0.26 \\
\hline EPA & $77 / 70$ & $0^{\mathrm{d}}$ & $2^{\mathrm{d}}$ & $13^{\mathrm{c}}$ & $22^{\mathrm{a}}$ & $19^{b}$ & $12^{\mathrm{c}}$ & $2^{\mathrm{d}}$ & $0^{\mathrm{d}}$ & $0^{\mathrm{d}}$ & $0^{\mathrm{d}}$ & $0^{\mathrm{d}}$ & $0^{\mathrm{d}}$ \\
\hline EPB & $77 / 64$ & $0^{\mathrm{e}}$ & $2^{\mathrm{d}}$ & $36^{\mathrm{a}}$ & $19^{\mathrm{b}}$ & $4^{c}$ & $1^{\mathrm{e}}$ & $0^{\mathrm{e}}$ & $1^{\mathrm{e}}$ & $1^{\mathrm{e}}$ & $0^{\mathrm{e}}$ & $0^{\mathrm{e}}$ & $0^{\mathrm{e}}$ \\
\hline
\end{tabular}

$\overline{\mathrm{a}, \mathrm{b}, \mathrm{c}, \mathrm{d}, \mathrm{e} \text { Values }}$ are different $(\mathrm{P}<0.01)$. 
resin collection period (Dos Santos et al. 2003); genetics of the queen bee (Park et al. 1998); local flora and collection region (Bankova 2005), among others. In spite of this, the values found in this paper were in accordance with the minimum limits set by the "Ministério de Agricultura, Pecuária e Abastecimento" (MAPA) of 5\% for total phenolic and 0.5\% for total flavonoids (Brasil 2001).

The obtained results confirmed that, the EPA and EPB contain considerable amounts of phenolic and flavonoids compounds, which were higher in EPA than EPB. In both extracts the total phenol content was higher than the total flavonoids content, a common finding for propolis from Brazil (Alencar et al. 2007, Moreira et al. 2008, Kalogeropoulos et al. 2009, Nunes et al. 2012, Coelho 2013), Greece, Cyprus (Kalogeropoulos et al. 2009), Czech Republic, Ireland and Germany (Al-Ani et al. 2018). The total phenol and flavonoids contents observed for EPA were similar to those of Kumazawa et al. (2004), El Sohaimy \& Masry (2014) and Silva et al. (2015), lower than Alencar et al. (2007), Cabral et al. (2012), Peixoto et al. (2012) and El Sohaimy \& Masry (2014), and higher than Tiveron et al. (2016). Cunha et al. (2004) observed a variation of 6.41 to $15.24 \%$ in the total phenol content, while Gonsales et al. (2006) verified variations between 0.05 and $0.63 \%$ in the contents of flavonoids and Sousa et al. (2007) verified a total flavonoid content of 0.06 to $0.38 \%$ for samples from São Paulo (Franca region) and from 0.12 to $2.11 \%$ for those from Minas Gerais (Passo region). This high variability in the total phenol and flavonoid content occurs due to the different sources of vegetable exudate, as well as by the location of the apiary (Park et al. 2002, Gonsales et al. 2006, Sousa et al. 2007). The soluble solids content in the both extract of propolis tested were higher than those observed by Sousa et al. (2007) and met the current legislation standards (Brasil 2001).

The HLPC-DAD analysis revealed mainly the presence of simple phenolic acids as caffeic, coumaric and cinnamic acids and methylated phenolic acids such as ferulic acid, and also 3,4-dihydroxybenzoic acid. These results agree with $\mathrm{Al}$ Naggar et al. (2016) that also found coumaric acid, ferulic acid and caffeic acid in Canadian propolis. Previous studies also have had describe presence of caffeic acid (Marcucci et al. 2001, Bankova et al. 2002, Kartal et al. 2002, 2003, Salomão et al. 2004, Ahn et al. 2007, Mohammadzadeh et al. 2007, Barbarić et al. 2011, Coelho 2013, El Sohaimy \& Masry 2014, Niculae et al. 2015, Oldoni et al. 2015, Tiveron et al. 2016, Al-Ani et al. 2018); coumaric acid (Mohammadzadeh et al. 2007, Barbarić et al. 2011, Coelho 2013, Niculae et al. 2015, Oldoni et al. 2015, Tiveron et al. 2016, Afrouzan et al. 2018, Al-Ani et al. 2018); cinnamic acid (Salomão et al. 2004, Yang et al. 2011, Coelho 2013, El Sohaimy \& Masry 2014, Tiveron et al. 2016, Al-Ani et al. 2018); and ferulic acid (Bankova et al. 2002, Kartal et al. 2002, Salomão et al. 2004, Ahn et al. 2007, Alencar et al. 2007, Mohammadzadeh et al. 2007, Barbarić et al. 2011, Coelho 2013, El Sohaimy \& Masry 2014, Niculae et al. 2015, Oldoni et al. 2015, Bakdash et al. 2018).

Coumaric and cinnamic acids were the main components in EPA and EPB, contrasting with the results by previous reports that found ferulic acid (Alencar et al. 2007, Barbarić et al. 2011, El Sohaimy \& Masry 2014, Niculae et al. 2015) caffeic acid (Kartal et al. 2002, Melliou \& Chinou 2004, El Sohaimy \& Masry 2014); p-coumaric acid (Jorge et al. 2008, Salomão et al. 2008, Afrouzan et al. 2018) and cinnamic acid (Katircioglu \&
Mercan 2006, Mohammadzadeh et al. 2007, Silva Filho et al. 2009) as the main component. Therefore, this was the first study to relate the joint action of cinnamic and coumaric acids to the antimicrobial activity of propolis, confirming that the propolis composition varies according to botanical and geographical origin (Bankova et al. 2002, Salomão et al. 2004, Bankova 2005, Popova et al. 2005, Sahinler \& Kaftanoglu 2005, Barbarić et al. 2011, Huang et al. 2014, Shahbaz et al. 2015, Afrouzan et al. 2018, Bakdash et al. 2018).

The results showed that both EPA and EPB showed antimicrobial activity against isolates of Staphylococcus spp., in agreement with previous studies indicated that the antibacterial activity of propolis is more pronounced against Gram-positive bacteria (Langoni et al. 1996, Sforcin et al. 2000, Pinto et al. 2001, Fernandes Júnior et al. 2003, Auricchio et al. 2006, Trusheva et al. 2010, Aguiar et al. 2014). The antibacterial activity of the EPA, with $90.9 \%$ susceptibility, was similar to the Loguercio et al. (2006) and Coelho et al. (2010) which showed susceptibility of $94.4 \%$ in coagulase-positive Staphylococcus. When comparing the two extracts, it was verified that isolates of Staphylococcus spp. susceptible to common antibiotics, as well as those resistant to oxacillin, showed higher susceptibility to EPA, while isolates susceptible to oxacillin showed greater susceptibility to EPB. It is believed that the higher levels of phenolic compounds in EPA have been responsible for the greater susceptibility of isolates resistant to oxacillin, since phenolic compounds to bind to bacterial cell walls and prevent cell division and gr owth, as also observed in previous reports (Stapleton et al. 2004, El Sohaimy 2014, Al-Ani et al. 2018).

EPA demonstrated potent antibacterial activity against Staphylococcus spp. isolates in lower concentrations than EPB. These results agree with Kareem et al. (2015) who also observed this activity in Iranian propolis against Staphylococcus spp. MBC for EPA (34.3-68.6 $\mu \mathrm{g} / \mathrm{mL}$ ) was similar to Cabral et al. (2009) and Rhajaoui et al. (2001); lower than Hayacibara et al. (2005), Alencar et al. (2007) and Tiveron et al. (2016) and higher than Santos et al. (2002) and Zeighampour et al. (2014). According to Cos et al. (2006), the ideal anti-infective concentration would be generally below $100 \mu \mathrm{g} / \mathrm{ml}$ for extracts, confirming the excellent efficiency of the EPA in relation to EPB and to others studies.

Staphylococcus spp. have a high ability to develop mechanisms of antimicrobial resistance, which makes them a serious problem of global public health (Ratti \& Sousa 2009, Garza-González et al. 2010, Reddy et al. 2017). This is the case with methicillin-resistant Staphylococcus aureus (MRSA) strains, which are resistant to all beta lactam antimicrobials (Adelman 2005), and often presents the multiple resistance phenomenon (Ratti \& Sousa 2009). EPA and EPB inhibited significantly $(100 \%)$ the clinical strains of MRSA and of S. aureus ATCC 6538 and ATCC 25923. Our results were similar to others reports in relation to the MRSA (Vera et al. 2011, Astani et al. 2013, Aguiar et al. 2014) and S. aureus ATCC 6538 (Hazem et al. 2017). In opposition, AL-Ani et al. (2018) observed a moderate anti-MRSA efficacy and Katircioglu \& Mercan (2006) a low efficacy against S. aureus ATCC 25923, reinforcing the importance of the evaluation of multiresistant strains in the tests of antimicrobial activity of natural products (Cos et al. 2006). Low MBC, like observed in this study, might be advantageous in therapeutic level for appropriate treatment 
of bacterial infections with regard to toxicity and stability of formulations (Astani et al. 2013).

The individual phenolic compounds present in the EPA and EPB were not identified and quantified, because submitting the entire extracts to antimicrobial activity studies seems to be more beneficial than to submit isolated constituents, since a bioactive individual component can change its properties in the presence of other compounds present in the extract (Borchers et al. 2004), corresponding to a synergistic effect.

The way propolis exerts its antimicrobial action is complex and occur, among other things, through inhibition of the bacteria growth by inhibiting of its enzymatic activity diminishing their effects on biological systems (Zeighampour et al. 2014); inhibition of cell division; collapse of the bacterial cytoplasm, cell membranes, and cell walls; bacteriolysis; and protein synthesis inhibition (Takaisi-Kikuni \& Schilcher 1994 apud Fernandes Junior et al. 2005). In vitro studies have attributed the antimicrobial activity of propolis to the presence of phenolic compounds, flavonoids, phenolic acids and their esters (Pinto et al. 2001, Freitas et al. 2005, Katircioglu \& Mercan 2006, Mohammadzadeh et al. 2007, Barbarić et al. 2011) or to the synergistic action of flavonoids and other active principles (Santos et al. 2002, Da Silva Filho et al. 2004, Barros et al. 2007, Sousa et al. 2007). Flavonoids (Uzel et al. 2005, Alencar et al. 2007, Cushnie \& Lamb 2011) and phenylethyl ester of caffeic acid apEPAr to act by inhibiting bacterial RNA polymerase (Uzel et al. 2005), while phenolic compounds, such as caffeic acid, benzoic acid and cinnamic acid, cause functional and structural damages on the membrane or cell wall of microorganisms (Scazzocchio et al. 2005) or inhibition of bacterial replication (Rastogi et al. 2008) and galagin and caffeic acid cause enzymatic inhibition in bacteria (Koo et al. 2002). The results suggest that the antibacterial activity of EPA and EPB occurred mainly due to the content of phenolic compounds as previously described (Bankova et al. 1995, Marcucci et al. 2001, Popova et al. 2005, Estevinho et al. 2008, Ristivojević et al. 2016, Al-Ani et al. 2018), in particular by the content of cumaric and cinnamic acids (Popova et al. 2005, Sforcin 2007). However, it can not be ruled out that different substances may be involved in the antimicrobial activity, since Cabral et al. (2012) observed that G6 propolis, which had the lowest phenolic compound and flavonoid contents, showed the best antibacterial effect.

\section{CONCLUSION}

We could confirm that both extracts of propolis, whose main constituents are cumin and cinnamic acids, have high antimicrobial activity against the microorganisms studied, and EPA had also a high antimicrobial activity against oxacillin-resistant strains. These findings reinforce its potential use for the treatment of bovine mastitis.

Acknowledgments.- The authors thank the "Programa de Apoio a Núcleos Emergentes" of "Fundação de Amparo à Ciência e Tecnologia do Estado de Pernambuco" (PRONEM-FACEPE), process no. 0741.1.06/14.

Conflict of interest statement.- The authors have no competing interests.

\section{REFERENCES}

Acosta A.C., Silva L.B.G., Medeiros E.S., Pinheiro-Júnior J.W. \& Mota R.A. 2016. Mastites em ruminantes no Brasil. Pesq. Vet. Bras. 36(7):565-573. <http:// dx.doi.org/10.1590/S0100-736X2016000700001>
Adelman J. 2005. Propolis: variabilidade composicional, correlação com a flora e bioatividade antimicrobiana/antioxidante. Master's Thesis in Farmaceutical Science, Universidade Federal do Paraná, Curitiba. 186p.

Afrouzan H., Tahghighi A., Zakeri S. \& Es-Haghi A. 2018. Chemical composition and antimicrobial activities of Iranian Propolis. Iranian Biomed. J. 22(1):5065. <PMid:28558440>

Aguiar C.G., Lima L.G. \& Athayde L.A. 2014. Efeito antimicrobiano da própolis verde frente a cEPAs de Staphylococcus aureus resistentes à meticilina (MRSA). Revta Bras. Pesq. Ciênc. Saúde 1(1):12-16.

Ahn M.-R., Kumazawa S., Usui Y., Nakamura J., Matsuka M., Zhu F. \& Nakayama T. 2007. Antioxidant activity and constituents of propolis collected in various areas of China. Food Chemistry 101(4):1383-1392.<http://dx.doi. org/10.1016/j.foodchem.2006.03.045>

Al Naggar Y., Sun J., Robertson A., Giesy J.P. \& Wiseman S. 2016. Chemical characterization and antioxidant properties of Canadian propolis. J. Apicultural Res. 55(4):305-314. <http://dx.doi.org/10.1080/0021883 9.2016.1233700>

Al-Ani I., Zimmermann S., Reichling J. \& Wink M. 2018. Antimicrobial activities of European propolis collected from various geographic origins alone and in combination with antibiotics. Medicines, Basel 5(1):2-17. <http://dx.doi. org/10.3390/medicines5010002><PMid:29301368>

Alencar S.M., Oldoni T.L., Castro M.L., Cabral I.S., Costa-Neto C.M., Cury J.A., Rosalen P.L. \& Ikegaki M. 2007. Chemical composition and biological activity of a new type of Brazilian propolis: red propolis. J. Ethnopharmacol. 113(2):278283. <http://dx.doi.org/10.1016/j.jep.2007.06.005><PMid:17656055>

Araújo K.C.S. \& Marcucci M.C. 2011. Efeito sinergístico da própolis tipificada contra Enterococcus faecalis. Revta Pesq. Inov. Farm. 3:9-14.

Astani A., Zimmermann S., Hassan E., Reichling J., Sensch K.H. \& Schnitzler P. 2013. Antimicrobial activity of propolis special extract GH 2002 against multidrug-resistant clinical isolates. Pharmazie 68(8):695-701. <PMid:24020127>

Auricchio M.T., Bugno A., Almodóvar A.A.B. \& Pereira T.C. 2006. Avaliação da atividade antimicrobiana de prEPArações de própolis comercializadas na cidade de São Paulo. Revta Inst. Adolfo Lutz 65(3):209-212.

Bakdash A., Almohammadi O.S., Taha N.A., Abu-Rumman A. \& Kumar S. 2018. Chemical Composition of Propolis from the Baha Region in Saudi Arabia. Czech J. Food Sci. 36:1-10.

Bankova V. 2005. Chemical diversity of propolis and the problem of standardization. J. Ethnopharmacol. 100(1):114-117. <http://dx.doi. org/10.1016/j.jep.2005.05.004><PMid:15993016>

Bankova V., Castro S.L. \& Marcucci M.C. 2000. Propolis: Recent advances in chemistry and plant origin. Apidologie 31(1):3-15. <http://dx.doi. org/10.1051/apido:2000102>

Bankova V., Christov R., Kujumgiev A., Marcucci M.C. \& Popov S. 1995. Chemical composition and antibacterial activity of Brazilian propolis. Z. Naturforsch. J. Biosci. 50(3/4):167-172. <PMid:7766255>

Bankova V., Popova M., Bogdanov S. \& Sabatini A.G. 2002. Chemical composition of European propolis: expected and unexpected results. Z. Naturforsch. J. Biosci. C 57(5/6):530-533. <http://dx.doi.org/10.1515/znc-2002-5-622> <PMid:12132697>

Barbarić M., Mišković K., Bojić M., Lončar M.B., Smolčić-Bubalo A., Debeljak Z. \& Medić-Šarić M. 2011. Chemical composition of the ethanolic propolis extracts and its effect on HeLa cells. J. Ethnopharmacol. 135(3):772-778. <http://dx.doi.org/10.1016/j.jep.2011.04.015><PMid:21515353>

Barberio A., Gietl H. \& Dalvit P. 2002. “In vitro” sensibilidade aos antimicrobianos de Staphylococcus aureus e coliformes isolados de mastite bovina na região de Veneto, Itália, no período de 1996-1999. Napgama 5(1):3-10.

Barbosa M.H., Zuffi F.B., Maruxo H.B. \& Jorge L.L.R. 2009. Therapeutic properties of propolis for treatment of skin lesions. Acta Paul. Enferm. 22(3):318-322. <http://dx.doi.org/10.1590/S0103-21002009000300013> 
Barros M.P., Sousa J.P., Bastos J.K. \& de Andrade S.F. 2007. Effect of Brazilian green propolis on experimental gastric ulcers in rats. J. Ethnopharmacol. 110 (3):567-571. <http://dx.doi.org/10.1016/j.jep.2006.10.022> <PMid:17126509>

Bean N.H. \& Griffin P.M. 1990. Foodborne disease outbreaks in the United States, 1973-1987: pathogens, vehicles, and trends. J. Food Protect. 53(9):804-817. <http://dx.doi.org/10.4315/0362-028X-53.9.804> <PMid:31018312>

Borchers A.T., Keen C.L. \& Gershwin M.E. 2004. Mushrooms, tumors, and immunity: an update. Exp. Biol. Med. 229(5):393-406. <http://dx.doi. org/10.1177/153537020422900507><PMid:15096651>

Brasil. Ministério da Agricultura 2001. Regulamento técnico para fixação de identidade e qualidade de própolis. Instrução Normativa nํㅜ 3, Anexo VI, de 19 de janeiro. Ministério da Agricultura, Brasília, DF.

Burdock G.A. 1998. Review of the biological properties and toxicity of bee propolis (Propolis). Food Chem. Toxicol. 36(4):347-363. <http://dx.doi. org/10.1016/S0278-6915(97)00145-2> <PMid:9651052>

Cabral I.S.R., Oldoni T.L.C., Alencar S.M., Rosalen P.L. \& Ikegaki M. 2012. The correlation between the phenolic composition and biological activities of two varieties of Brazilian propolis (G6 and G12). Braz. J. Pharm. Sci. 48(3):557-564. <http://dx.doi.org/10.1590/S1984-82502012000300023>

Cabral I.S.R., Oldoni T.L.C., Prado A., Bezerra R.M.N., Alencar S.M., Ikegaki M. \& Rosalen P.L. 2009. Composição fenólica, atividade antibacteriana e antioxidante da própolis vermelha brasileira. Quím. Nova 32(6):1523-1527. <http://dx.doi.org/10.1590/S0100-40422009000600031>

Chen Y.-W., Ye S.-R., Ting C. \& Yu Y.-H. 2018. Antibacterial activity of propolins from Taiwanese green propolis. J. Food Drug Anal. 26(2):761-768. <http:// dx.doi.org/10.1016/j.jfda.2017.10.002> <PMid:29567247>

Clinical and Laboratory Stardards Institute. National Committee for Clinical Laboratory Standards. Methods for broth dilution susceptibility testing of bacteria isolated from aquatic animals; approved guideline. Wayne, PA: 2006. (CLSI/NCCLS Document M49-A)

Coelho J.P.M. 2013. Identificação e quantificação de compostos fenólicos em própolis da região sul do Brasil. Avaliação da atividade antioxidante por técnicas espectroscópicas e eletroquímicas. Master's Thesis, Universidade de Salamanca, Bragança, Portugal. 57p.

Coelho M.S., Silva J.H., Oliveira E.R.A., Amâncio A.L.L., Silva N.V. \& Lima R.M.B. 2010. A própolis e sua utilização em animais de produção. Arch. Zootec. 59(R):95-112.

Cos P., Vlietinck A.J., Berghe D.V. \& Maes L. 2006. Anti-infective potential of natural products: how to develop a stronger in vitro 'proof-of concept'. J. Ethnopharmacol. 106(3):290-302. <http://dx.doi.org/10.1016/j. jep.2006.04.003> <PMid:16698208>

Costa E.0. 2001. Uso de antimicrobianos na mastite, p.443-445. In: Spinosa H.S., Gorniak S.L. \& Bernardi M. (Eds), Farmacologia Aplicada à Medicina Veterinária. Guanabara Koogan, Rio de Janeiro.

Cunha I.B.S., Sawaya A.C.H.F., Caetano F.M., Shimizu M.T., Marcucci M.C., Drezza F.T., Povia G.S. \& Carvalho P.O. 2004. Factors that influence the yield and composition of brazilian propolis extracts. J. Braz. Chem. Soc. 15(6):964970. <http://dx.doi.org/10.1590/S0103-50532004000600026>

Cushnie T.P.T. \& Lamb A.J. 2011. Recent advances in understanding the antibacterial properties of flavonoids. Int. J. Antimicrob. Agents 38(2):99-107. <http://dx.doi.org/10.1016/j.ijantimicag.2011.02.014><PMid:21514796>

Dalmora S., de Oliveira J.E., Affonso R., Gimbo E., Ribela M.T. \& Bartolini P. 1997. Analysis of recombinant human growth hormone directly in osmotic shock fluids. J. Chromatogr. A 782(2):199-210.<http://dx.doi.org/10.1016/ S0021-9673(97)00493-7><PMid:9368400>

De Castro S.L. 2001. Propolis: biological and pharmacological activities. Therapeutic uses of this bee-product. ARBS 3:49-83.

Dos Santos C.R., Arcenio F., Carvalho E.S., Lúcio E.M.R.A., Araújo G.L., Teixeira L.A., Sharapin N. \& Rocha L. 2003. Otimização do processo de extração de própolis através da verificação da atividade antimicrobiana. Revta Bras. Farmacogn. 13:71-4.

El Sohaimy S.A. 2014. Chemical composition, antioxidant and antimicrobial potential of artichoke. Open Nutraceuticals J. 7:15-20.

El Sohaimy S.A. \& Masry S.H.D. 2014. Phenolic content, antioxidant and antimicrobial activities of Egyptian and Chinese propolis. Am. Eurasian J. Agric. Environ. Sci. 14(10):1116-1124.

Endler A.L., Oliveira S.C., Amorim C.A., Carvalho M.P. \& Pileggi M. 2003. Teste de eficácia da própolis no combate a bactérias patogênicas das vias respiratórias. Ciênc. Biol. Saúde 9(2):17-20.

Erskine R.J., Wagner S. \& De Graves F.J. 2003. Mastitis therapy and pharmacology. Vet. Clin. N. Am., Food Anim. Pract. 19(1):109-138.

Estevinho L., Pereira A.P., Moreira L., Dias L.G. \& Pereira E. 2008. Antioxidant and antimicrobial effects of phenolic compounds extracts of Northeast Portugal honey. Food Chem. Toxicol. 46(12):3774-3779. <http://dx.doi. org/10.1016/j.fct.2008.09.062><PMid:18940227>

European Pharmacopoeia 2002. European Pharmacopoeia 4th ed. Council of Europe, Strasbourg.

Fernandes Júnior A., Balestrin E.C.C. \& Cunha M.L.R.S. 2003. Anti-Staphylococcus aureus activity of bee propolis extracts prepared with different ethanol concentrations. Revta Ciênc. Farm. 24:147-152.

Fernandes Júnior A., Balestrin E.C., Betoni J.E.C., Orsi R.O., Cunha M.L.R.S. \& Montelli A.C. 2005. Propolis: anti-Staphylococcus aureus activity and synergism with antimicrobial drugs. Mem. Inst. Oswaldo Cruz 100(5):563-566. <http:// dx.doi.org/10.1590/S0074-02762005000500018><PMid:16184236>

Freitas M.F.L., Pinheiro Junior J.W., Stamford T.L.M., Rabelo S.S.A., Silva D.R., Silveira Filho V.M., Santos F.G.B. \& Mota R.A. 2005. Perfil se sensibilidade antimicorbiana in vitro de Staphylococcus coagelusa positivos isolados de leite de vaca com mastite no agreste do Estado e Pernambuco. Arq. Inst. Biológico, São Paulo, 72(2):171-177.

García-Lafuente A., Guillamón E., Villares A., Rostagno M.A. \& Martínez J.A 2009. Flavonoids as anti-inflammatory agentes: implications in cancer and cardiovascular disease. Inflamm. Res. 58(9):537-552. <http://dx.doi. org/10.1007/s00011-009-0037-3><PMid:19381780>

Garza-González E., Morfin-Otero R., Llaca-Diaz J.M. \& Rodriguez-Noriega E. 2010. Staphylococcal cassette chromosome mec (SCC mec) in methicillinresistant coagulase-negative staphylococci. A review and the experience in a tertiarycare setting. Epidemiol. Infect. 138(5):645-654. <http://dx.doi. org/10.1017/S0950268809991361><PMid:19961645>

Gonsales G.Z., Orsi R.O., Fernandes Junior A., Rodrigues P. \& Funari S.R.C. 2006. Antibacterial activity of propolis collected in different regions of Brazil. J. Venom. Anim. Toxins Trop. Dis. 12(2):276-284. <http://dx.doi. org/10.1590/S1678-91992006000200009>

Hayacibara M.F., Koo H., Rosalen P.L., Duarte S., Franco E.M., Bowen W.H., Ikegaki M. \& Cury J.A. 2005. In vitro and in vivo effects of isolated fractions of Brazilian propolis on caries development. J. Ethnopharmacol. 101(1/3):110115. <http://dx.doi.org/10.1016/j.jep.2005.04.001><PMid:15913934>

Hazem A., Popescu C.V., Crișan I., Popa M., Chifiriuc M.C., Pircalabioru S. \& Lupuliasa D. 2017. Antibacterial efficiency of five propolis extracts planktonic and adherent microbial strains. Farmacia 65(5):813-818.

Hogeveen H., Huijps K. \& Lam T.J. 2011. Economic aspects of mastitis: new developments. N. Z. Vet. J. 59(1):16-23. <http://dx.doi.org/10.1080/004 80169.2011.547165> <PMid:21328153>

Huang S., Zhang C.P., Wang K., Li G.Q. \& Hu F.L. 2014. Recent advances in the chemical composition of propolis. Molecules 19(12):19610-19632. <http://dx.doi.org/10.3390/molecules191219610><PMid:25432012>

Instituto Adolfo Lutz 1976. Métodos Químicos e Físicos para Análise de Alimentos. Vol.1. $2^{\text {a }}$ ed. Normas analíticas do Instituto Adolfo Lutz, Instituto Adolfo Lutz, São Paulo. 1000p. 
Jorge R., Furtado N.A.J.C., Sousa J.P.B., Silva Filho A.A., Gregorio J.L.E., Martins C.H.G., Soares A.E.E., Bastos J.K., Cunha W.R. \& Silva M.L.A. 2008. Brazilian propolis: seasonal variation of the prenylated p-coumaric acids and antimicrobial activity. Pharm. Biol. 46(12):889-893. <http://dx.doi. org/10.1080/13880200802370373>

Kalogeropoulos N., Konteles S.J., Troullidou E., Mourtzinos I. \& Karathanos V.T. 2009. Chemical composition, antioxidant activity and antimicrobial properties of propolis extracts from Greece and Cyprus. Food Chem. 116(2):452-461. <http://dx.doi.org/10.1016/j.foodchem.2009.02.060>

Kareem A.A., Abdzaid N.Y., Salman R.M., Mohamed M.K., Dekel A.J. \& AbdulMuhsen R.S. 2015. Study of antibacterial activity in the local Iraqi propolis. J. Contemporary Med. Sci. 1(2):6-8.

Kartal M., Kaya S. \& Kurucu S. 2002. GC-MS analysis of propolis samples from two different regions of Turkey. Z. Naturforsch. 57(9/10):905-909. <http:// dx.doi.org/10.1515/znc-2002-9-1025><PMid:12440732>

Kartal M., Yıldız S., Kaya S., Kurucu S. \& Topçu G. 2003. Antimicrobial activity of pro- polis samples from two different regions of Anatolia. J. Ethnopharmacol. 86(1):69-73. <http://dx.doi.org/10.1016/S0378-8741(03)00042-4> $<$ PMid:12686444>

Katircioglu H. \& Mercan N. 2006. Antimicrobial activity and chemical compositions of of Turkish propolis from different regions. African J. Biotechnol. 5(11):1151-1153.

Koo H., Rosalen P.L., Cury J.A., Park Y.K. \& Bowen W.H. 2002. Effects of compounds found in propolis on Streptococcus mutans growth and on glucosiltransferase activity. Antimicrob. Agents Chemother. 46(5):1302-1309. <http://dx.doi. org/10.1128/AAC.46.5.1302-1309.2002><PMid:11959560>

Kumazawa S., Hamasaka T. \& Nakayama T. 2004. Antioxidant activity of propolis of various geographic origins. Food Chem. 84(3):329-339.<http:// dx.doi.org/10.1016/S0308-8146(03)00216-4>

Langoni H. 2000. Tendências de modernização do setor lácteo: monitoramento da qualidade do leite pela contagem de células somáticas. Revta Ed. Contin. CRMV-SP 3(3):57-64.

Langoni H., Domingues P.F., Funari S.R.C., Chande C.G. \& Neves I.R. 1996. Efeito antimicrobiano in vitro da propolis. Arq. Bras. Vet. Zoot. 48(2):227-229.

Lee Y.K., Yang P., Mishchenko M.I., Baum B.A., Hu Y.X., Huang H.L., Wiscombe W.J. \& Baran A.J. 2003. Use of circular cylinders as surrogates for hexagonal pristine ice crystals in scattering calculations of infrared wavelengths. Appled Optics 42(15):2653-2664. <http://dx.doi.org/10.1364/A0.42.002653> <PMid:12777000>

Loguercio A.P., Groff M.C.A., Pedrozzo F.A., Witt M.N., Silva S.M. \& Vargas C.A. 2006. Atividade in vitro do extrato de própolis contra agentes bacterianos da mastite bovina. Pesq. Agropec. Bras. 41(2):347-349. <http://dx.doi. org/10.1590/S0100-204X2006000200021>

Lustosa S.R., Galindo A.B., Nunes L.C.C., Randau K.P. \& Rolim Neto P.J. 2008. Própolis: atualizações sobre a química e a farmacologia. Revta Bras. Farmacogn. 18(3):447-454. <http://dx.doi.org/10.1590/S0102695X2008000300020>

Marcucci M. 1995. Propolis: chemical composition, biological properties and therapeutic activity. Apidologie 26(2):83-99. <http://dx.doi.org/10.1051/ apido:19950202>

Marcucci M.C., Ferreres F., Garcia-Viguera C., Bankova V.S., Castro S.L., Dantas A.P., Valente P.H.M. \& Paulino N. 2001. Phenolic compounds from Brazilian propolis with pharmacological activities. J. Ethnopharmacol. 74(2):105-112. <http://dx.doi.org/10.1016/S0378-8741(00)00326-3><PMid:11167028>

Martins R.P., Silva J.A.G., Nakazato L., Dutra V. \& Almeida Filho E.S. 2010. Prevalência e etiologia infecciosa da mastite bovina na microrregião de Cuiabá, MT. Ciênc. Anim. Bras. 11(1):181-187. <http://dx.doi.org/10.5216/ cab.v11i1.5085>

Meda A., Lamien C., Romito M., Millogo J. \& Nacoulma 0. 2005. Determination of the total phenolic, flavonoid and proline contents in Burkina Fasan honey, as well as their radical scavenging activity. Food Chem. 91(3):571-577. <http://dx.doi.org/10.1016/j.foodchem.2004.10.006>

Melliou E. \& Chinou I. 2004. Chemical analysis and antimicrobial activity of Greek propolis. Planta Med. 70(6):515-519. <http://dx.doi. org/10.1055/s-2004-827150><PMid:15229802>

Mohammadzadeh S., Shariatpanahi M., Hamedi M., Ahmadkhaniha R., Samadi N. \& Ostad S.N. 2007. Chemical composition, oral toxicity and antimicrobial activity of Iranian propolis. Food. Chem. 103(4):1097-1103. <http://dx.doi. $\operatorname{org} / 10.1016 / j$.foodchem.2006.10.006>

Moreira L., Dias L.G., Pereira J.A. \& Estevinho L. 2008. Antioxidant properties, total phenols and pollen analysis of propolis samples from Portugal. Food Chem. Toxicol. 46(11):3482-3485. <http://dx.doi.org/10.1016/j. fct.2008.08.025><PMid:18804144>

NCCLS 2002. Performance Standards for Antimicrobial Susceptibility Testing. National Committee For Clinical Laboratory Standards, Wayne, PA, p.133.

Nero L.A., Mattos M.R., Beloti V., Barros M.A.F. \& Franco B.D.G.M. 2007. Resíduos de antibióticos em leite cru de quatro regiões leiteiras no Brasil. Revta Ciênc. Tecnol. Aliment. 27(2):391-393.<http://dx.doi.org/10.1590/ S0101-20612007000200031>

Niculae M., Stan L., Pall E., Paștiu A.I., Balaci J.M., Muste S. \& Spînu M. 2015. In vitro synergistic antimicrobial activity of romanian propolis and antibiotics against Escherichia coli isolated from bovine mastitis. Notulae Botanicae Horti Agrobotanaci 43(2):327-334. <http://dx.doi.org/10.15835/ nbha43210074>

Nunes C.F., Finger P.F., Fischer G., Castro C.C., Hübner S.O., Paulino N., Marcucci M.C., Vieira O., Martes P.E. \& Vargas G.D. 2012. Padronização de uma Amostra de Extrato Etanólico de Própolis Verde. Revta Fitos 7(1):67-72.

Oldoni T.L.C., Oliveira S.C., Andolfatto S., Karling M., Calegari M.A., Sado R.Y., Maia F.M.C., Alencar S.M. \& Lima V.A. 2015. Chemical characterization and optimization of the extraction process of bioactive compounds from propolis produced by selected bees Apis mellifera. J. Braz. Chem. Soc. 26:2054-2062.

Omoe K., Ishikawa M., Shimoda Y., Hu D., Ueda S. \& Shinagawa K. 2002. Detection of seg, she, and sei genes in Staphylococcus aureus isolates and determination of the enterotoxin productivities of Staphylococcus aureus isolates harborin seg, seh, or sei genes. J. Clin. Microbiol. 40(3):857-862. <http://dx.doi.org/10.1128/JCM.40.3.857-862.2002><PMid:11880405>

Park Y.I.A., Ikegaki M., Abreu J.A.S. \& Alcici N.M.F. 1998. Estudo da prEPAração dos extratos de própolis e suas aplicações. Ciênc. Tecnol. Aliment. 18(3):313318. <http://dx.doi.org/10.1590/S0101-20611998000300011>

Park Y.K., Alencar S.M. \& Aguiar C.L. 2002. Botanical origin and chemical composition of Brazilian propolis. J. Agric. Food Chem. 50(9):2502-2506. <http://dx.doi.org/10.1021/jf011432b><PMid:11958612>

Peixoto E.C.T.M., Jardim J.G., Heinzen E.L., Domingues P.F., Padovani C.R. \& Orsi R.O. 2012. Própolis no controle da mastite bovina. Arch. Vet. Sci. 17(4):43-52.

Pereira A.S., Seixas F.R.M.S. \& Aquino Neto F.R. 2002. Propolis: 100 years of research and its future. Quím. Nova 25(2):321-326. <http://dx.doi. org/10.1590/S0100-40422002000200021>

Pietta P.G., Gardana C. \& Pietta A.M. 2002. Analytical methods for quality control of propolis. Fitoterapia 73(Suppl.1):S7-S20.<http://dx.doi.org/10.1016/ S0367-326X(02)00186-7><PMid:12495705>

Pinto M.S., Faria J.E., Message D., Cassini S.T.A., Pereira C.S. \& Gioso M.M. 2001. Efeito de extratos de própolis verde sobre bactérias patogênicas isoladas do leite de vacas com mastite. Braz. J. Vet. Res. Anim. Sci. 38(6):278-283. <http://dx.doi.org/10.1590/S1413-95962001000600006>

Popova M., Silici S., Kaftanoglu O. \& Bankova V. 2005. Antibacterial activity of Turkish propolis and its qualitative and quantitative chemical composition. Phytomedicine 12(3):221-228. <http://dx.doi.org/10.1016/j. phymed.2003.09.007><PMid:15830845> 
Rastogi N., Domadia P., Shetty S. \& Dasgupta D. 2008. Screening of natural phenolic compounds for potential to inhibit bacterial cell division protein FtsZ. Indian. J. Exp. Biol. 46(11):783-787. <PMid:19090350>

Ratti R.P. \& Sousa C.P. 2009. Staphylococcus aureus meticilina resistente (MRSA) e infecções nosocomiais. Revta Ciênc. Farm. Básica Apl. 30(2):137-143.

Reddy B.V., Kusuma Y.S., Pandav C.S., Goswami A.K. \& Krishnan A. 2017. Water and sanitation hygiene practices for under-five children among households of Sugali tribe of Chittoor District, Andhra Pradesh, India. J. Environ. Publ. Health 2017:1-7. <http://dx.doi.org/10.1155/2017/7517414> $<$ PMid:28642797>

Rhajaoui M., Ourmazil H., Faid M., Lyagoubi M., Elyachioui M. \& Benjouad A. 2001. Antibacterial activity of a Moroccan propolis extracts. Sci. Letters 3(3):201-207.

Ribeiro M.G. 2008. Princípios terapêuticos na mastite em animais de produção e de companhia, p.759-771. In: Andrade S.F. (Ed.), Manual de Terapêutica Veterinária. $3^{a}$ ed. Roca, São Paulo.

Ribeiro M.G., Geraldo J.S., Langoni H., Lara G.H.B., Siqueira A.K., Salerno T. \& Fernandes M.C. 2009. Microrganismos patogênicos, celularidade e resíduos de antimicrobianos no leite bovino produzido no sistema orgânico. Pesq. Vet. Bras. 29(1):52-58. <http://dx.doi.org/10.1590/ S0100-736X2009000100008>

Ristivojević P., Dimkić I., Trifković J., Berić T., Vovk I., Milojković-Opsenica D. \& Stanković S. 2016. Antimicrobial activity of serbian propolis evaluated by means of MIC, HPTLC, bioautography and chemometrics. Plos One 11(6):115. <http://dx.doi.org/10.1371/journal.pone.0157097><PMid:27272728>

Roesler R., Malta L.G., Carrasco L.C., Holanda R.B., Sousa C.A.S. \& Pastore G.M. 2007. Atividade antioxidante de frutos do cerrado. Ciênc. Tecnol. Aliment. 27(1):53-60. <http://dx.doi.org/10.1590/S0101-20612007000100010>

Rufatto L.C., Santos D.A., Marinho F., Henriques J.A.P., Ely M.R. \& Moura S. 2017. Red propolis: chemical composition and pharmacological activity. Asian Pac. J. Trop. Biomed. 7(7):591-598. <http://dx.doi.org/10.1016/j. apjtb.2017.06.009>

Russi N.B., Bantar C. \& Calvinho L.F. 2008. Antimicroial susceptibility os Staphylooccus aureus causing bovine mastitis in Argentine dairy herds. Revta Argent. Microbiol. 40(2):116-119. <PMid:18705495>

Saeki E.K., Mello-Peixoto E.C.T., Matsumoto L.S., Marcusso P.F. \& Monteiro R.M. 2012. Mastite bovina por Staphylococcus aureus: sensibilidade às drogas antimicrobianas e ao extrato alcoólico de própolis. Acta Vet. Bras. 5:284-290. <http://dx.doi.org/10.21708/avb.2011.5.3.2172>

Sahinler N. \& Kaftanoglu O. 2005. Natural product propolis: chemical composition. Nat. Prod. Res. 19(2):183-188. <http://dx.doi.org/10.108 0/14786410410001704877><PMid:15715264>

Salomão K., Dantas A.P., Borba C.M., Campos L.C., Machado D.G., Aquino Neto F.R. \& De Castro S.L. 2004. Chemical composition and microbicidal activity of extracts from Brazilian and Bulgarian propolis. Lett. Appl. Microbiol. 38(2):87-92. <http://dx.doi.org/10.1111/j.1472-765X.2003.01458.x> <PMid:14746537>

Salomão K., Pereira P.R.S., Campos L.C., Borba C.M., Cabello P.H., Marcucci M.C. \& Castro S.L. 2008. Brazilian propolis: correlation between chemical composition and antimicrobial activity. Evid. Based Complement. Alternat. Med. 5(3):317-324. <http://dx.doi.org/10.1093/ecam/nem058> $<$ PMid:18830454>

Santos F.A., Bastos E.M.A., Uzeda M., Carvalho M.A.R., Farias L.M., Moreira E.S.A. \& Braga F.C. 2002. Antibacterial activity of Brazilian propolis and fractions against oral anaerobic bacteria. J. Ethnopharmacol. 80(1):1-7. <http://dx.doi.org/10.1016/S0378-8741(02)00003-X><PMid:11891080>

Santos F.G.B., Mota R.A., Silveira V.M., Souza H.M., Oliveira M.B.M., Johner J.M.Q., Leal N.C., Almeida A.M.P. \& Balbino T.C.L. 2003. Tipagem molecular de Staphylococcus aureus isolados do leite de vacas com mastite subclínica e equipamentos de ordenha procedentes do estado de Pernambuco. Napgama 6(1):19-23.
Santos M.V. \& Fonseca L.F.L. 2007. Estratégias para o Controle de Mastite e Melhoria da Qualidade do Leite. Manole, São Paulo. 314p.

Scazzocchio F., D'auria F.D., Alessandrini D. \& Pantanella F. 2005. Multifactorial aspects of antimicrobial activity of propolis. Microbiol. Res. 4(4):327-333. <http://dx.doi.org/10.1016/j.micres.2005.12.003> <PMid:16427259>

Schiavon D.B.A., Schuch L.F.D., Oyarzabal M.E.B., Prestes L.S., Zani J.L. \& Hartwig C.A. 2011. Aplicación de plantas medicinales para la antisepsia de pezones de vacas posordeño. Revta Cubana Plant. Med. 16(3):253-259.

Sforcin J.M. 2007. Propolis and the immune system. Rev. J. Ethnopharmacol. 113(1):1-14.<http://dx.doi.org/10.1016/j.jep.2007.05.012><PMid:17580109>

Sforcin J.M., Fernandes Junior A., Lopes C.A., Bankova V. \& Funari S.R. 2000. Seasonal effect on Brazilian propolis antibacterial activity. J. Ethnopharmacol. 73(1/2):243-249. <http://dx.doi.org/10.1016/S0378-8741(00)00320-2> <PMid:11025162>

Shahbaz M., Zahoor T., Randhawa M.A. \& Nawaz H. 2015. In vitro antibacterial activity of hydroalcoholic extract of propolis against pathogenic bacteria. Pakistan J. Life Soc. Sci. 13(3):132-136.

Shi D., Hao Y., Zhang A., Wulan B. \& Fan X. 2010. Antimicrobial resistance of Staphylococcus aureus isolanted from bovine mastitis in China. Transbound Emerg. Dis. 57(4):221-224. <PMid:20557495>

Silva Filho A.A., Bueno P.C.P., Gregorio L.E., Silva M.L.A., Albuquerque S. \& Bastos J.K. 2004. In vitro trypanocidal activity evaluation of crude extract and isolated compounds from Baccharis dracunculifolia D. C. (Asteraceae). J. Pharm. Pharmacol. 56(9):1195-1199. <http://dx.doi. org/10.1211/0022357044067> <PMid:15324490>

Silva Filho A.A., Resende D.O., Fukui M.J., Santos F.F., Pauletti P.M., Cunha W.R., Silva M.L., Gregório L.E., Bastos J.K. \& Nanayakkara N.P. 2009. In vitro antileishmanial, antiplasmodial and cytotoxic activities of phenolics and triterpenoids from Baccharis dracunculifolia D. C. (Asteraceae). Fitoterapia 80(8):478-482. <http://dx.doi.org/10.1016/j.fitote.2009.06.007> <PMid:19540316>

Silva L.A.F., Silva E.B., Romani A.F. \& Garcia A.M. 2004. Causas de descarte de fêmeas bovinas leiteiras adultas. Revta Bras. Saúde. Prod. Anim. 5:9-17.

Silva W.E.L., Ferrari Junior W.D., Rosa P.R., Peixoto R.M., Tenório J.A.B., Silva T.M.S. \& Costa M.M. 2015. In vitro activit of propolis: Synergism in combination with antibiotic against Staphylococcus spp. African J. Microbiol. Res. 9(1):1-5. <http://dx.doi.org/10.5897/AJMR2014.7173>

Singleton V.L. \& Rossi Junior J.A. 1965. Colorimetry of total phenolics with phosphomolybdic-phosphotungstic acid reagents. Am. J. Enol. Viticulture 16:144-158.

Sousa J.P.B., Furtado N.A.J.C., Jorge R., Soares A.E.E. \& Bastos J.K. 2007. Perfis físico-químico e cromatográfico de amostras de própolis produzidas nas microrregiões de Franca (SP) e Passos (MG), Brasil. Braz. J. Pharmacogn. 17(1):85-93. <http://dx.doi.org/10.1590/S0102-695X2007000100017>

Spohr M., Rau J., Friedrich A., Klittich G., Fetsch A., Guerra B., Hammerl J.A. \& Tenhagen B.A. 2011. Methicilin-resistent Staphylooccus aureus (MRSA) in three dairy herds in southwest Germany. Zoonoses Publ. Health 58(4):252-261. <http://dx.doi.org/10.1111/j.1863-2378.2010.01344. $\mathrm{x}><$ PMid:20630047>

Stapleton P.D., Shah S., Anderson J.C., Hara Y., Hamilton-Miller J.M.T. \& Taylor P.W. 2004. Modulation of beta-lactam resistance in Staphylococcus aureus by catechins and gallates. Int. J. Antimicrob. Agents 23(5):462-467. <http:// dx.doi.org/10.1016/j.ijantimicag.2003.09.027> <PMid:15120724>

Taubes G. 2008. The bacteria fight back. Science 321(5887):356-361. <http:// dx.doi.org/10.1126/science.321.5887.356><PMid:18635788>

Tiveron A.P., Rosalen P.L., Franchin M., Lacerda R.C.C., Bueno-Silva B., Benso B., Denny C., Ikegaki M. \& Alencar S.M. 2016. Chemical characterization and antioxidant, antimicrobial, and anti-inflammatory activities of south Brazilian organic propolis. PLoS One 11(11):e0165588. <http://dx.doi. org/10.1371/journal.pone.0165588><PMid:27802316> 
Trusheva B., Todorov I., Ninova M., Najdenski H., Daneshmand A. \& Bankova V. 2010. Antibacterial mono- and sesquiterpene esters of benzoic acids from Iranian propolis. Chem. Central J. 4(8):1-5. <http://dx.doi.org/10.1186/1752153X-4-8><PMid:20350297>

Uzel A., Sorkun K., Onçağ O., Cogŭlu D., Gençay O. \& Salih B. 2005. Chemical compositions and antimicrobial activities of four different Anatolian propolis samples. Microbiol. Res. 160(2):189-195. <http://dx.doi.org/10.1016/j. micres.2005.01.002> <PMid:15881836>

Vera N., Solorzano E., Ordoñez R., Maldonado L., Bedascarrasbure E. \& Isla M.I. 2011. Chemical composition of Argentinean propolis collected in extreme regions and its relation with antimicrobial and antioxidant activities. Nat. Prod. Commun. 6(6):823-827. <http://dx.doi.org/10.1177/1934578X1100600618> <PMid:21815419>
Vianni M.C.E. \& Lázaro N.S. 2003. Perfil de suscetibilidade a antimicrobianos em amostras de cocos Gram-positivos, catalase negativos, isolados de mastite subclínica bubalina. Pesq. Vet. Bras. 23(2):47-51. <http://dx.doi. org/10.1590/S0100-736X2003000200001>

Yang H., Dong Y., Du H., Shi H., Peng Y. \& Li X. 2011. Antioxidant compounds from propolis collected in Anhui, China. Molecules 16(4):3444-3455. <http://dx.doi.org/10.3390/molecules16043444> $<$ PMid:21512452>

Zeighampour F., Mohammadi-Sichani M., Shams E. \& Naghavi N.S. 2014. Antibacterial activity of propolis ethanol extract against antibiotic resistance bacteria isolated from burn wound infections. Zahedan J. Res. Med.Sci. 16(3):25-30. 